\title{
Massive calcinosis cutis associated with primary Sjögren's syndrome
}

\author{
Yumi Tsuchida, Shuji Sumitomo, Keishi Fujio, Kazuhiko Yamamoto
}

Department of Allergy and Rheumatology, The University of Tokyo, Tokyo, Japan

\section{Correspondence to} Dr Shuji Sumitomo, sumitos-tky@umin.ac.jp

Accepted 14 January 2016

\section{DESCRIPTION}

A 28-year-old Japanese woman presented with subcutaneous nodules on the extensor surface of her elbows and knees, which had been present for 6 years. Radiographs of the knees showed numerous calcifications, up to $13 \mathrm{~mm}$ in diameter, in the subcutaneous tissue on the extensor side of those joints, consistent with calcinosis cutis (figure 1).

The patient's renal function, serum calcium, phosphorus and parathyroid hormone levels were normal, and there was no evidence suggesting a metabolic disorder. Antinuclear antibody $(40 \times$, speckled) and anti-Sjögren's syndrome antigen A (SSA) antibody were positive. Although her subjective symptoms of dry eyes and dry mouth were mild, parotid sialography showed stage two salivary gland disease with collections of contrast material measuring $1-2 \mathrm{~mm}$ in diameter throughout the gland (figure 2). There were no signs of other connective tissue diseases (CTD), hence, based on the revised Japanese criteria for Sjögren's syndrome, ${ }^{1}$ the patient was diagnosed with primary Sjögren's syndrome (pSS). There were signs of neither
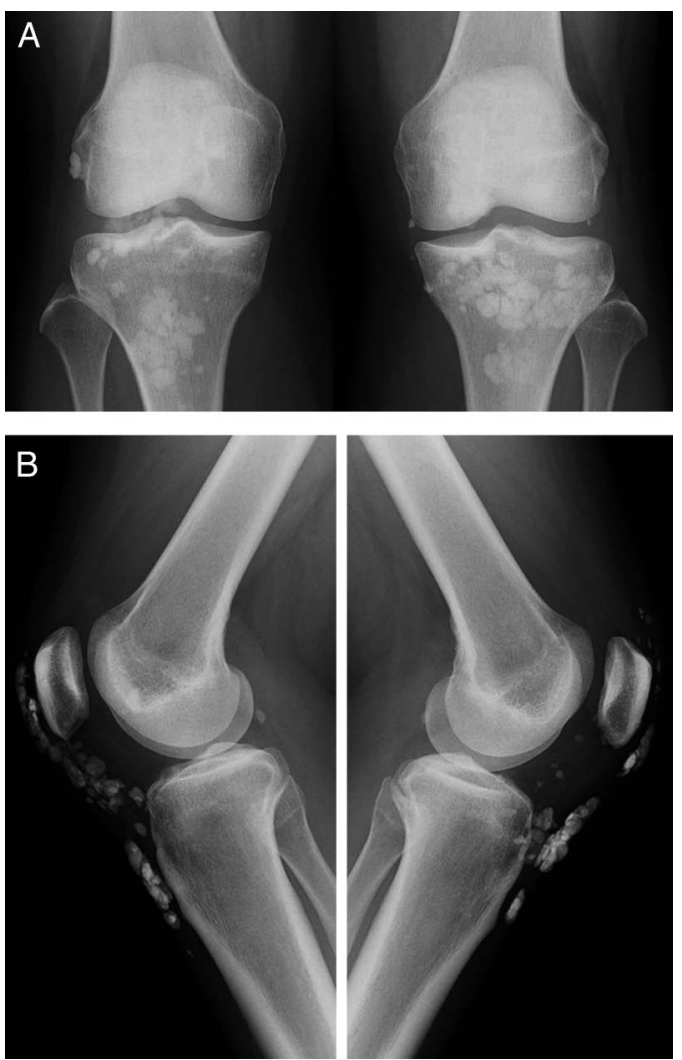

Figure 1 (A) Frontal and (B) lateral radiographs of the knees, showing numerous calcifications in the subcutaneous tissue.

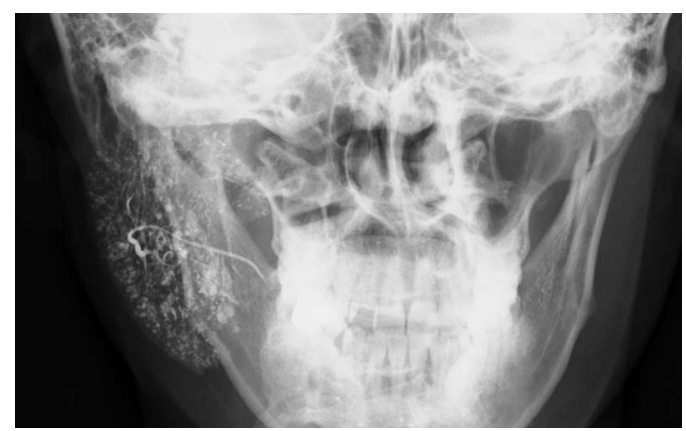

Figure 2 Parotid sialography showing stage two salivary gland disease.

nephrocalcinosis nor of renal tubular acidosis. Treatment with diltiazem was ineffective, and surgical excision of the lesions was performed with no recurrence after 7 months of follow-up.

Calcinosis cutis has been reported to occur in association with various CTD, most commonly with systemic scleroderma and dermatomyositis. There have been two reports of calcinosis cutis associated with pSS in the English literature: one in the fingertips of a 55-year-old woman ${ }^{2}$ and another in the hands of a 74-year-old man. ${ }^{3}$ However, to the best of our knowledge, calcifications this massive have not been reported in association with pSS before.

\section{Learning points}

- Primary Sjögren's syndrome may be associated with calcinosis cutis.

- Surgical excision of the lesions may be effective for this condition.

Contributors $Y T$ and SS wrote the manuscript and provided the figures. $\mathrm{KF}$ and $\mathrm{KY}$ supervised the manuscript.

Competing interests None declared.

Patient consent Obtained.

Provenance and peer review Not commissioned; externally peer reviewed.

\section{REFERENCES}

1 Fujibayashi T, Sugai S, Miyasaka N, et al. Revised Japanese criteria for Sjögren's syndrome (1999): availability and validity. Mod Rheumatol 2004;14:425-34.

2 Llamas-Velasco M, Eguren C, Santiago D, et al. Calcinosis cutis and Sjögren's syndrome. Lupus 2010;19:762-4.

3 Fueki H, Hino R, Yoshioka M, et al. Calcinosis cutis associated with primary Sjögren's syndrome: strong expression of osteonectin and matrix Gla protein. Rheumatology (Oxford) 2011;50:2318-20. 
Copyright 2016 BMJ Publishing Group. All rights reserved. For permission to reuse any of this content visit http://group.bmj.com/group/rights-licensing/permissions.

BMJ Case Report Fellows may re-use this article for personal use and teaching without any further permission.

Become a Fellow of BMJ Case Reports today and you can:

- Submit as many cases as you like

- Enjoy fast sympathetic peer review and rapid publication of accepted articles

- Access all the published articles

- Re-use any of the published material for personal use and teaching without further permission

For information on Institutional Fellowships contact consortiasales@bmjgroup.com

Visit casereports.bmj.com for more articles like this and to become a Fellow 